\title{
CHARACTERIZATION AND PROBIOTIC POTENTIALS OF LACTIC ACID BACTERIA ISOLATED FROM INGESTA OF SELECTED RUMINANTS
}

\author{
E.I. Nnawuine, K. Banwo*, K. And A.I. SAnni \\ Department of Microbiology, University of Ibadan, Oyo State. Nigeria
}

(Received: 18 March 2017; accepted: 23 June 2017)

\begin{abstract}
Studies were carried out to isolate and screen lactic acid bacteria with probiotic potentials and amylolytic activities from the ruminal ingesta of cow and goat. Ninety isolates obtained from the three abattoirs were divided into the following species: Lactobacillus plantarum, L. fermentum, L. pentosus, L. brevis, L. buchneri, L. collinoides, and Leuconostoc mesenteroides. The isolates were screened for probiotic potentials and amylolytic activities. Four isolates possessed probiotic potentials: L. plantarum CA3b, L. fermentum GA2d, L. plantarum GA1d, and L. plantarum GA3e. Lactobacillus plantarum CA3b, L. fermentum GA2d, and L. plantarum GA3e survived pH 2.5 and 3.5 after $180 \mathrm{~min}$. Lactobacillus plantarum GA1d had the highest tolerance of $82.44 \%$ and $71.03 \%$ to $0.3 \%$ and $1 \%$ bile salts concentrations, respectively. Lactobacillus plantarum CA3b hydrolysed 3\% starch with an average zone of clearance of $10.0 \mathrm{~mm}$, while L. plantarum GA1d hydrolysed $\%$ with a zone of $9.5 \mathrm{~mm}$. These two strains also possessed bacteriocin activities against $E$. coli, and were characterised based on their reactions to $\mathrm{pH}$, temperature, and enzymes treatments. Ruminal ingesta of cow and goat harbour lactic acid bacteria possessing amylolytic and probiotic potentials, which can be exploited in the fermentation of feedstock, conferring health benefits and improved performance to these ruminants.
\end{abstract}

Keywords: ruminal ingesta, lactic acid bacteria, probiotics, amylolytic activity

Ruminants are mammals of the order Artiodactyla (Davis \& MiLner, 2009). They have four chambered stomach made up of the reticululum, rumen, omasum, and abomasum (DeноRITY \& Tirabasso, 2000; Davis \& Milner, 2009). Ruminant animals such as cow, sheep, goat, and deer, however, do not synthesize fibre digesting enzymes, but they have formed a symbiotic relationship with ruminal microorganisms that do (DEhoRity \& TiRABasso, 2000).

The microbial quality of the ingesta (ingested food) depends to a large extent on the quality and composition of feed stuff (Belanche et al., 2012; Uyeno et al., 2015). The microbial flora of the ingesta is a function of the nature, quality, and composition of the animals' feed, which is dominated by complex polysaccharide and starch degrading microbiota. Lactic acid bacteria (LAB) among other bacteria and fungi found in the ingesta of ruminants have been isolated and documented (BELANCHE et al., 2012; Uyeno et al., 2015). These are added as bacteriocin producing cultures or by the addition of pure or semi-pure bacteriocin preparations. Several LAB have been isolated from intestinal tracts of ruminants. These include species of the genera Lactococcus, Leuconostoc, Streptococcus, Pediococcus, Ruminococcus, and Lactobacillus (Fraga et al., 2013; Uyeno et al., 2015).

Lactic acid bacteria constitute an integral part of the healthy gastrointestinal (GI) microecology and are involved in the host metabolism. A number of mechanisms work to prevent harmful bacteria from growing and attaching to the intestinal epithelium, examples include

\footnotetext{
* To whom correspondence should be addressed.

Phone: +234-8056100840; e-mail: kolabanwo@yahoo.com
} 
production and secretion of antimicrobial agents such as bacteriocins and organic acids, and adherence via competition for the binding sites interfering with pathogens (REID et al., 2001; WANG et al., 2010).

The aim of this study was to screen various isolates of LAB from ruminal ingesta of cow and goat for the possible exploitation as potential probiotics and starter culture(s) for feedstock of ruminant diet.

\section{Materials and methods}

\subsection{Collection of samples}

Samples were obtained from healthy cattle (cow and goat) from three selected abattoirs; the University of Ibadan Teaching and Research farm and Bodija and Moniya cattle markets in Ibadan, South West Nigeria. Three cows and three goats were sampled from each cattle farm at each sampling time. The sampling was carried out at five different times from each farm. Samples were collected immediately after evisceration from the recticulo-rumen with the assistance of a qualified veterinarian assigned to each abattoir.

1.1.1. Isolation of $L A B$. The samples obtained from the cows and goats were homogenized separately. A total of $10 \mathrm{~g}$ per $100 \mathrm{ml}(\mathrm{w} / \mathrm{v})$ of the homogenized sample were stored in normal saline for 5 h. A 10-fold serial dilution was made using $10 \mathrm{ml}$ stock sample into $90 \mathrm{ml}$ distilled water. These were cultured for 48 h in de Man Rogosa Sharpe agar (MRS) using pour plate method under anaerobic conditions. They were further sub-cultured in MRS agar under anaerobic conditions until pure isolates were obtained. Pure cultures were maintained as stocks in MRS broth at $-4{ }^{\circ} \mathrm{C}$, with $15 \%$ glycerol.

\subsection{Biochemical characterization of the $L A B$ isolates}

1.2.1. Carbohydrates fermentation. Biochemical characterization was carried out on the isolates by assimilation of carbohydrates using API 50CH strips and API 50CHL medium (Biomérieux, Marcy Etoile, France) according to the instructions of the manufacturer. The results from the assimilation profiles were identified using the Apiweb ${ }^{\mathrm{TM}}$ software version 5.1 .

\subsection{Probiotic potentials of the selected $L A B$ isolates}

1.3.1. Resistance to low $\mathrm{pH}$. The ability of the isolates to tolerate low $\mathrm{pH}$ was determined according to the method of Vinderola and ReINHEIMER (2003). The mixture was enumerated for the presence of viable cells after 1,2 , and $3 \mathrm{~h}$ by measuring the optical density (OD) at $560 \mathrm{~nm}$ wavelength using a spectrophotometer (Jenway UV-Vis 5210, Essex, UK), and the results were compared with a control.

1.3.2. Bile tolerance and hydrophobicity tests. Bile salt tolerance and hydrophobicity were assayed by the method of Vinderola and Reinheimer (2003). Hydrophobicity was calculated as the percentage decrease in the $\left(\mathrm{OD}_{600 \mathrm{~nm}}\right)$ of the initial aqueous bacterial suspension due to cells partitioning into a hydrocarbon layer. The percentage of cell surface hydrophobicity $(\% \mathrm{H})$ of the strain adhering to xylene was calculated using the equation: $\mathrm{H} \%=[(\mathrm{A} 0-\mathrm{A}) / \mathrm{A} 0 \times 100]$. 


\subsection{Starch hydrolysis}

Surface dried plates of starch based MRS agar [1, 2, and 3\% starch (w/v)] (SAnNi et al., 2002) were streaked with $18 \mathrm{~h}$ old culture of $\mathrm{LAB}$ and incubated at $30^{\circ} \mathrm{C}$ for 3 days. The plates were flooded with Gram`s iodine solution for 15 to 30 min and examined for clear zones around the growth for assessment of amylolytic activity.

\subsection{Genotypic characterization of the selected amylolytic LAB isolates}

The genomic DNA of the selected amylolytic LAB strains were extracted using the modified lysozyme-heat lysis method. The DNA quantity and purity were determined using a spectrophotometer at absorbance reading of $260 \mathrm{~nm}$ (Nanodrop, Thermo Scientific, USA). The partial 16S rRNA nucleotide sequence was amplified by PCR using universal primers designed for lactic acid bacteria, forward was (5' - GAG TTT GAT CCT GGC TCA G - 3'), while the reverse was (5' - AGA AAG GAG GTG ATC CAG CC - 3') (BAnwo et al., 2012). The PCR products were cleaned using spin columns and subsequently sequenced in a commercial laboratory (Beijing, China).

\subsection{Antimicrobial activities of selected LAB isolates}

The antibacterial activity of the selected isolates against indicator pathogens Listeria monocytogenes, Escherichia coli, Klebsiella pneumoniae, and Pseudomonas aeruginosa were determined. The isolates were grown in MRS broth $(\mathrm{pH}$ 6.5) inoculated with $1 \%$ of an overnight culture and incubated at $37^{\circ} \mathrm{C}$ for $18-24 \mathrm{~h}$. After incubation, cells were removed from the growth medium by centrifugation $\left(6000 \times g\right.$ for $\left.20 \mathrm{~min}, 4^{\circ} \mathrm{C}\right)$. The antimicrobial spectrum of the inhibitory substances from LAB was determined using the agar well diffusion method (AWD) and observed for zones of inhibition (SCHILLINGER \& LÜCKE, 1989).

1.6.1. Screening for bacteriocin producing isolates. The cell-free supernatants of LAB were adjusted to $\mathrm{pH} 6.0-6.5$ using $5 \mathrm{~N} \mathrm{NaOH}$ to exclude the antimicrobial effect of organic acids. Inhibitory activity of hydrogen peroxide was eliminated by the addition of catalase at a final concentration of $1.0 \mathrm{mg} \mathrm{ml}^{-1}$. The catalase-treated samples were incubated for $2 \mathrm{~h}$ at $37^{\circ} \mathrm{C}$. After incubation, the treated and neutralized cell-free supernatants were then tested for antagonistic activity against indicator bacteria by the AWD (SCHILLINGER \& LÜCKE, 1989).

1.6.2. Characterization of bacteriocin. The bacteriocins were subjected to treatment at different temperatures, $\mathrm{pH}$, and enzymes. The enzymes were added to $1 \mathrm{ml}$ of neutralized cell free culture supernatant to a final concentration of $2.0 \mathrm{mg} \mathrm{ml}^{-1}$ in all cases. The tubes were incubated at $37^{\circ} \mathrm{C}$ for $1 \mathrm{~h}$ and the residual bacteriocin activities were determined by measuring the zones of inhibition on agar plates (BANwo et al., 2013). Untreated cell free supernatants were used as control.

\subsection{Statistical analyses}

Each experiment described in this research study was done in replicates and data obtained from the study were analysed using descriptive statistics and analysis of variance. The differences among means were separated using Duncan's multiple range test. Significant differences were accepted at P>0.05. The statistical software used was SPSS 16.5 for Windows 7. 


\section{Results and discussion}

\subsection{Characterization of LAB isolates using API 50CHL Kit}

Ninety LAB isolates were biochemically characterized into the following species of Lactobacillus plantarum (32), L. fermentum (25), L. pentosus (15), L. brevis (4), L. buchneri (4), L. collinoides (3), and Leuconostoc mesenteroides (7) (data not shown). The assessment of biochemical and physiological properties of lactic acid bacteria maybe a good method for phenotypic characterization, but it is not adequate (MoHAmmed et al., 2011; BANwo et al., 2012). There were differences in the species of LAB isolates from each ruminant in a particular sampling site, which agreed with the report of BELANCHE and co-workers (2012), that the different species isolated from the rumen (recticulo-rumen) is largely dependent on nutrition and health status of the ruminant. Selection of the isolates was based on the desirable properties of probiotic potentials and amylolytic activities.

\subsection{Resistance to low $\mathrm{pH}$}

The results of colony forming units $\left(\mathrm{CFU} \mathrm{ml}{ }^{-1}\right.$ ) are shown in Table 1 . In this study, it was observed that some strains tolerated $\mathrm{pH} 2.5$ and 3.5 for three hours, which is in agreement with previous reports of probiotic LAB (BANwo et al., 2013). Some authors proposed that strains intended for probiotic purposes should be screened according to their tolerance to $\mathrm{pH}$ 2.5 in an HCl-acidified culture medium for 3 hours (WANG et al., 2010; MoHAMmED et al., 2011).

Table 1. Survival count of selected LAB strains on exposure to $\mathrm{pH} 3.5$ and $2.5\left(\log _{10} \mathrm{CFU} \mathrm{ml}^{-1}\right)$

\begin{tabular}{lcccc}
\hline Isolate & \multicolumn{3}{c}{$\mathrm{pH}$} \\
\cline { 2 - 5 } & $\begin{array}{c}2.5 \\
(0 \mathrm{~min})\end{array}$ & $\begin{array}{c}2.5 \\
(\text { after } 180 \mathrm{~min})\end{array}$ & $\begin{array}{c}3.5 \\
(0 \mathrm{~min})\end{array}$ & $\begin{array}{c}3.5 \\
(\text { after } 180 \mathrm{~min})\end{array}$ \\
\hline L. plantarum CA3b & $4.76 \pm 0.03^{\mathrm{a}}$ & $2.29 \pm 0.34^{\mathrm{b}}$ & $5.17 \pm 0.01^{\mathrm{c}}$ & $3.11 \pm 0.21^{\mathrm{b}}$ \\
L. plantarum GA1d & $4.76 \pm 0.13^{\mathrm{a}}$ & - & $4.22 \pm 0.43^{\mathrm{d}}$ & - \\
L. fermentum GA2d & $4.65 \pm 0.03^{\mathrm{b}}$ & $2.74 \pm 0.15^{\mathrm{a}}$ & $5.97 \pm 0.31^{\mathrm{a}}$ & $4.11 \pm 0.19^{\mathrm{a}}$ \\
L. plantarum GA3e & $4.08 \pm 0.03^{\mathrm{d}}$ & $2.17 \pm 0.14^{\mathrm{c}}$ & $5.11 \pm 0.01^{\mathrm{c}}$ & $3.11 \pm 0.12^{\mathrm{b}}$ \\
\hline
\end{tabular}

Values are means of three independent experiments (mean $\pm \mathrm{SD}$ )

-: No visible growth/loss of viability; C: cow; G: goat; A: animal; 1: University of Ibadan Teaching and Research farm; 2: Bodija cattle farm; 3: Moniya cattle farm; b;d;e: sampling periods

Values with the same letters in superscript along a column are not significantly different $(\mathrm{P}>0.05)$.

\subsection{Bile salt tolerance}

The isolates from this study grew at $0.3 \%$ bile salt concentration, however, tolerance varied at higher concentrations of $0.5 \%$ and $1.0 \%$ (Fig. 1). Though the bile concentrations in the gastrointestinal tract vary, the mean concentration is $0.3 \% \mathrm{w} / \mathrm{v}$ (VINDEROLA \& REINHEIMER 2003). Interestingly, the strains stable at low $\mathrm{pH}$ were also bile salt tolerant. This is similar to the result obtained by WANG and co-workers (2010), who reported that the strains of $L$. buchneri, L. brevis, and L. plantarum were resistant to $0.3 \%$ bile salt at $\mathrm{pH} 4.0$. 


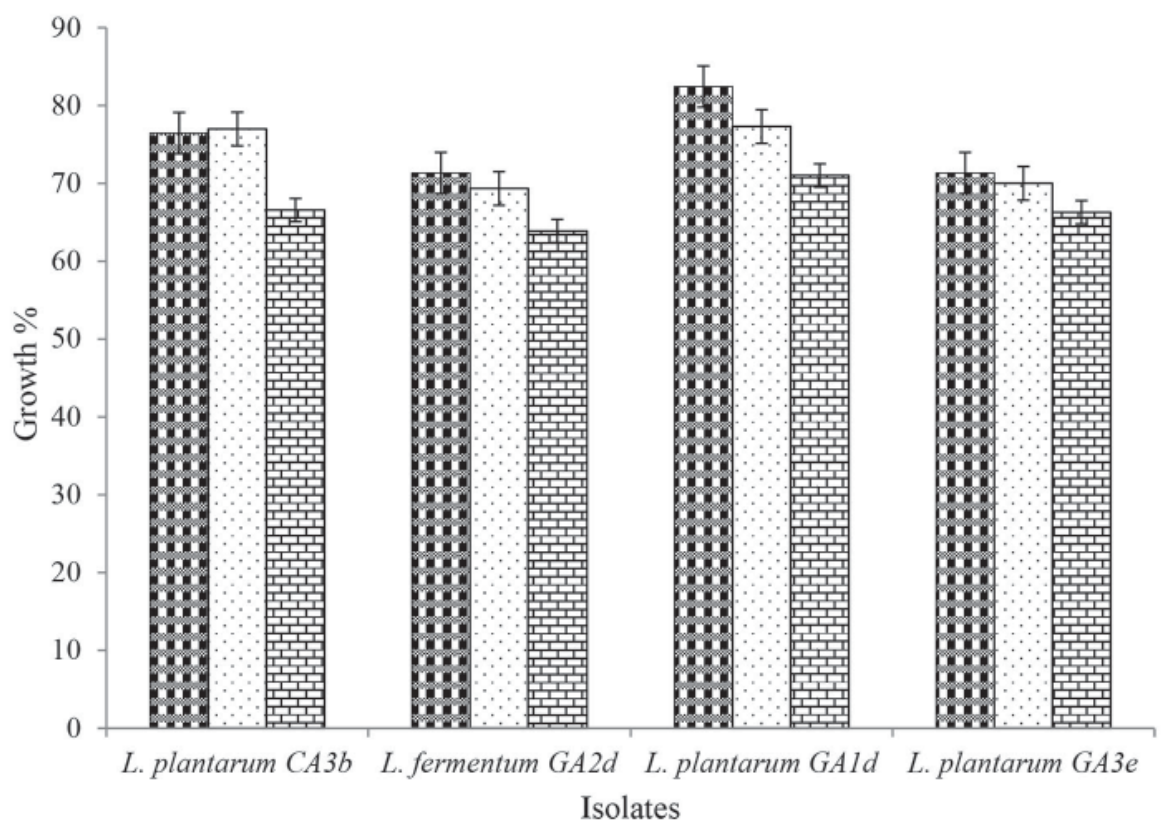

Fig. 1. Percentage bile salt tolerance of selected LAB strains to $0.3 \%, 0.5 \%$, and $1.0 \%$ bile salt concentrations. C: cow; G: goat; A: animal; 1: University of Ibadan Teaching and Research farm; 2: Bodija cattle farm; 3: Moniya cattle farm; a,b,c,d,e: sampling periods.

Bars represent the mean and standard deviations of three independent determinations 8: $0.30 \%$; 䍘: 0.50\%; 目:1.00\%

\subsection{Bacterial adhesion to hydrocarbon assay (BATH) and starch hydrolysis activities of the strains}

The selected LAB isolates were screened for their cell surface hydrophobicity as shown in Table 2. The gastrointestinal tract, especially the small intestine, is a dynamic environment, and the flow of digesta washes out any bacterium unable to counter the flow either by rapidly multiplying or by attaching itself to intestinal surfaces (MонAммED et al., 2011; GiтıкA \& TiwARI, 2013; Uyeno et al., 2015). Amylase is an enzyme, which breaks down starch into simple sugars. Consequently, only few lactic acid bacteria possess the ability to hydrolyse starch to produce amylase. The selected isolates demonstrated amylase activity by showing clear zones of hydrolysis on starch based MRS agar plates. Only one isolate, L. plantarum CA3b displayed the ability to hydrolyse 3\% starch concentration (Table 2). Very few amylolytic lactic acid bacteria (ALAB) are reported from traditional fermentation of food and feedstock (SANNi et al., 2002; REDDY et al., 2008). Potential probiotic LAB able to hydrolyse starch will be an added advantage in the fermentation of feedstock with added health benefit. The two isolates that possessed amylolytic potentials were identified using 16S rRNA gene sequencing as L. plantarum CA3b and L. plantarum GA1d with accession numbers MF099794 and MF099795, respectively. 
Table 2. Cell surface hydrophobicity and starch hydrolysis assay of the selected LAB strains

\begin{tabular}{|c|c|c|c|c|c|c|}
\hline \multirow[t]{2}{*}{ Isolates } & \multicolumn{3}{|c|}{ Hydrophobicity (\%) } & \multicolumn{3}{|c|}{$\begin{array}{l}\text { Starch concentration } \\
\text { (w/v) }\end{array}$} \\
\hline & Initial value & Final value & Adherence & 1 & 2 & 3 \\
\hline L. plantarum CA3b & $1.04 \pm 0.40$ & $0.31 \pm 0.03$ & $70.19 \pm 0.07^{c}$ & $+*$ & $+*$ & + \\
\hline L. plantarum GA1d & $1.06 \pm 0.40$ & $0.30 \pm 0.02$ & $71.70 \pm 0.06^{\mathrm{c}}$ & $+*$ & + & - \\
\hline L. fermentum GA2d & $1.31 \pm 0.02$ & $0.21 \pm 0.03$ & $83.97 \pm 0.08^{\mathrm{d}}$ & + & - & - \\
\hline L. plantarum GA3e & $1.06 \pm 0.04$ & $0.33 \pm 0.01$ & $68.87 \pm 0.07^{\mathrm{b}}$ & + & - & - \\
\hline
\end{tabular}

Values are expressed as the mean \pm standard deviation of three independent determinations

Values with the same letters in superscript along a column are not significantly different $(\mathrm{P}>0.0 .5)$. C: cow; G: goat; A: animal; 1: University of Ibadan Teaching and Research farm; 2: Bodija cattle farm; 3: Moniya cattle farm; b;d;e: sampling periods

-: No visible amylolytic activity (no visible zone of clearance); +: Amylolytic activity; +*: Strong amylolytic activity. Experiments were carried out at $37^{\circ} \mathrm{C}$ over 5 days

\subsection{Antimicrobial activities, production and characterization of crude bacteriocin}

Crude cell free culture supernatants of strains were tested against common pathogens as indicator microorganisms (Table 3). After neutralization of the cell free culture supernatants, four strains demonstrated antagonistic activities against E. coli. As previously reported, the antagonistic activities of LAB towards pathogens can be attributed to the production of bactericidal substances like bacteriocins, organic acids, and hydrogen peroxide (TALPUR et al., 2012; FrAGA et al., 2013).

Table 3. Zones of inhibition (mm) of antimicrobial action of cell free culture supernatant obtained from the LAB strains against indicator microorganisms before and after neutralization

\begin{tabular}{lccccc}
\hline Isolates & & \multicolumn{2}{c}{$\begin{array}{c}\text { ZI before neutralization } \\
\text { Indicator microorganisms }\end{array}$} & & \multicolumn{2}{c}{$\begin{array}{c}\text { ZI after } \\
\text { neutralization }\end{array}$} \\
\cline { 2 - 6 } & $\begin{array}{c}\text { Escherichia } \\
\text { coli }\end{array}$ & $\begin{array}{c}\text { Listeria } \\
\text { monocytogenes }\end{array}$ & $\begin{array}{c}\text { Klebsiella } \\
\text { pneumoniae }\end{array}$ & $\begin{array}{c}\text { Pseudomonas } \\
\text { aeruginosa }\end{array}$ & $\begin{array}{c}\text { Escherichia } \\
\text { coli }\end{array}$ \\
\hline L. plantarum CA3b & $25.0 \pm 0.08^{\mathrm{a}}$ & $24.4 \pm 0.09^{\mathrm{b}}$ & $22.4 \pm 0.11^{\mathrm{a}}$ & $19.0 \pm 0.12^{\mathrm{a}}$ & $18.0 \pm 0.08^{\mathrm{b}}$ \\
L. plantarum GA1d & $24.0 \pm 0.09^{\mathrm{b}}$ & $21.3 \pm 0.11^{\mathrm{c}}$ & $16.3 \pm 0.20^{\mathrm{d}}$ & $17.0 \pm 0.21^{\mathrm{c}}$ & $18.3 \pm 0.08^{\mathrm{b}}$ \\
L. fermentum GA2d & $21.1 \pm 0.10^{\mathrm{c}}$ & $16.4 \pm 0.21^{\mathrm{d}}$ & $18.0 \pm 0.12^{\mathrm{b}}$ & $18.0 \pm 0.20^{\mathrm{b}}$ & $19.7 \pm 0.06^{\mathrm{a}}$ \\
L. plantarum GA3e & $23.1 \pm 0.10^{\mathrm{C}}$ & $22.2 \pm 0.11^{\mathrm{c}}$ & $17.1 \pm 0.15^{\mathrm{c}}$ & $18.0 \pm 0.20^{\mathrm{b}}$ & - \\
\hline
\end{tabular}

Activity expressed as average zone of inhibition (mm). (P>0.0.5), C: cow; G: goat; A: animal; 1: University of Ibadan Teaching and Research farm; 2: Bodija cattle farm; 3: Moniya cattle farm; b;d;e: sampling periods. Each test was carried out at $30{ }^{\circ} \mathrm{C}$ for $18-24$ hours. Values with the same letters in superscript along a column are not significantly different $(\mathrm{P}>0.0 .5)$.

Tables 4 show the effect of $\mathrm{pH}$, temperature, and enzyme treatments on bacteriocins produced by the amylolytic strains $L$. plantarum CA3b and $L$. plantarum GA1d against $E$. coli. The activity of the bacteriocins produced was not significantly affected by $\mathrm{pH} 4.0$ to 8.0, but activity was highest at $\mathrm{pH}$ 6.0, while there was no activity at $\mathrm{pH} 9.0$. Maximum activity was observed at $\mathrm{pH}$ 6.0, suggesting that compounds other than acids inhibited growth (BANwo et al., 2013). 


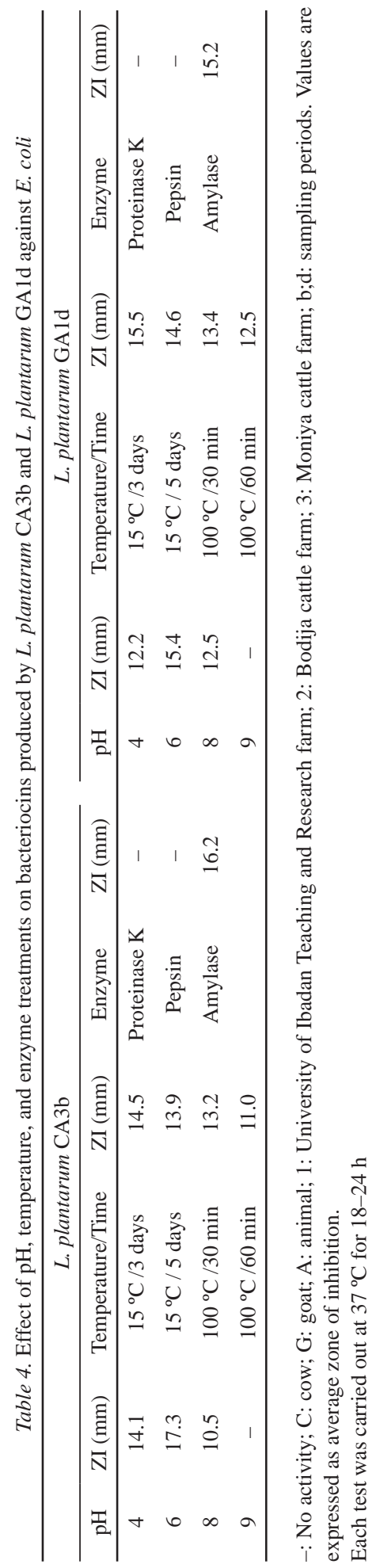


The bacteriocins were stable at $15{ }^{\circ} \mathrm{C}$ and $100{ }^{\circ} \mathrm{C}$ temperature for 30 and $60 \mathrm{~min}$, but activity was lost at $121^{\circ} \mathrm{C}$ for $15 \mathrm{~min}$. This supports the findings of ToDorov and co-workers (2011), they observed that bacteriocin GP1 produced by Lb. rhamnosus had a remarkable stability over heat treatment even at the autoclaving temperature for $20 \mathrm{~min}$. Heat stability of bacteriocins produced by lactic acid bacteria at $100{ }^{\circ} \mathrm{C}$ is important as a food biopreservative. Complete inactivation was observed after treatment of the cell-free supernatant with pepsin and proteinase $\mathrm{K}$, which confirmed the proteinaceous nature of the active agent. Amylase treatment did not result in inactivation. This implies that carbohydrate moiety if existing in the culture supernatant is not significantly responsible for the inhibitory activity. Similar results were recorded by ToDOROv and co-workers (2011) for bacteriocins produced by L. plantarum ST13BR. They observed that only proteolytic enzymes neutralized the activities of the bacteriocins.

\section{Conclusions}

The strains identified as Lactobacillus plantarum CA3b and Lactobacillus plantarum GA1d in this study produced bacteriocins and possessed amylolytic activities together, which is a very rare quality in the literature of lactic acid bacteria. Nature and composition of feedstock and other ecological factors could be associated with this factor. The lactic acid bacteria isolated possessed the generally regarded as safe status, which enable them to be employed as potential starter cultures for the fermentation of feedstock for enhanced performance.

The authors appreciate Prof. Yin Li and Mr. Liangtan Miao of the Centre of Excellence for Biotechnology, Institute of Microbiology, Chinese Academy of Sciences for the molecular characterization of the two strains that possess amylolytic activities.

\section{References}

Banwo, K., Sanni, A.I., TAn, H. \& Tian, Y. (2012): Phenotypic and genotypic characterization of LAB isolated from Nigerian traditional fermented foods. Food Biotechnol., 26, 124-142.

Banwo, K., Sanni, A. \& TAN, H. (2013): Functional properties of Pediococcus species isolated from traditional fermented cereal gruel and milk in Nigeria. Food Biotechnol., 27(1), 14-38.

Belanche, A., Doreau, M., Edwards, J.E., Moorby, J.M., Pinloche, E. \& Newbold, C.J. (2012): Shifts in the rumen microbiota due to the type of carbohydrate and level of protein ingested by dairy cattle are associated with changes in rumen fermentation. J. Nutr., 142(9), 1684-1692.

DAVIS, C.D. \& Milner, J.A. (2009): Gastrointestinal microflora, food components and colon cancer prevention. J. Nutr. Biochem., 20, 743-752.

Dehority, B.A. \& Tirabasso, P.A. (2000): Antibiosis between ruminal bacteria and ruminal fungi. Appl. Environ. Microb., 66, 2921-2927.

Fraga M.I., Perelmuter, K.I., Valencia, M.J., Cajarville, C. \& Zunino, P.J. (2013): Characterization of the ruminal bacterial microbiota of a grazing bovine through classical and culture independent methods. Veterinaria, 49, 40-55.

GitikA, S. \& TiWARI, S.K. (2013): Probiotic potential of Lactic acid bacteria strain LD/4. Int. J. Pharm. Life Sci., 4(10), 3000-3006.

Mohammed, B., Naoual, J. \& Abdelaziz, B. (2011): Probiotic potential of Lactobacillus strains isolated from known popular traditional Moroccan milk. Br. Microbiol. Res. J., 1(4), 79-94. 
Reddy, G., Altaf, Md., Naveena, B.J. Venkateshwar, M., \& Vijay Kumar, E. (2008): Amylolytic bacterial lactic acid fermentation - A review. Biotechnol. Adv., 26(1), 22-34.

Reid, G., Cuperus, P.L., Bruce, A.W., Van Der Mel, H.C., Tomzek, L., Khoury, A.H. \& Bussches, H.J. (2001): Comparison of contact angles and adhesion to hexadecane of urogenital, dairy, and poultry lactobacilli: effect of serial culture passages. Appl. Environ. Microb., 58, 1549-1553.

Sanni, A.I., Morlon-Guyot, J. \& Guyot, J.P. (2002): New efficient amylase-producing strain of Lactobacillus fermentum isolated from different Nigerian traditional fermented foods. Int. J. Food Microbiol., 72, 53-62.

SCHILlinger, U. \& LÜCKE F. (1989): Antibacterial activity of Lactobacillus sake isolated from meat. Appl. Environ. Microb., 55(8), 1901-1906.

Talpur, A.D., Memon, A.J., Khan, M.I., Ikhwanuddin, M., Danish, M.M., Daniel, M. \& Abolmunafi, A.B. (2012): Inhibition of pathogens by lactic acid bacteria and application as water additive multi isolates in early stages larviculture of P. pelagicus (Linnaeus, 1758). J. Anim. Plant Sci., 22(1), 54-64.

Todorov, S.D., Rachman, C., Fourrier, A., Dicks, L., Van Reenew, C., Prévost, H. \& Dousset, X. (2011): Characterization of a bacteriocin produced by Lactobacillus sakei R1333 isolated from smoked salmon. Anaerobe, 17(1), 23-31.

Uyeno, Y., Shigemori, S. \& Shimosato, T. (2015): Effect of probiotics/prebiotics on cattle health and productivity. Microbes Environ., 30(2), 126-132.

Vinderola, C.G. \& Reinheimer, J.A. (2003): Lactic acid starter and probiotic bacteria: a comparative in vitro study of probiotic characteristics and biological barrier resistance. Food Res. Int., 36, 895-904.

Wang, C.Y., Lin, P.R., NG, C.C. \& ShyU, Y.T. (2010): Probiotic properties of Lactobacillus strains isolated from the feces of breast-fed infants and Taiwanese pickled cabbage. Anaerobe, 166, 578-585. 